\title{
Soft Tissue Sarcoma of the Abdomen and Thoracic Visceral Organs TNM Finding v8
}

National Cancer Institute

\section{Source}

National Cancer Institute. Soft Tissue Sarcoma of the Abdomen and Thoracic Visceral

Organs TNM Finding v8. NCI Thesaurus. Code C136724.

A finding about one or more characteristics of soft tissue sarcoma of the abdomen and thoracic visceral organs, following the rules of the TNM AJCC v8 classification system. This classification system does not apply to desmoplastic small round cell tumor, epithelioid hemangioendothelioma, inflammatory myofibroblastic tumor, perivascular epithelioid cell tumor (PEComa), solitary fibrous tumor, gastrointestinal stromal tumor (GIST), uterine leiomyosarcoma, and retroperitoneal leiomyosarcoma. This is a new classification system and there is no recommended prognostic stage grouping at this time. (from AJCC 8th Ed.) 